\title{
Keragaman Morfologi dan Komponen Hasil Kubis Bunga (Brassica oleracea var. botrytis L.) di Dataran Tinggi dan Dataran Rendah
}

\section{Morphological Variability and Yield Component of Cauliflower (Brassica oleracea var. botrytis L.) in the High and Low Elevations}

\author{
Dyra Haryanti ${ }^{1}$, Darda Efendi ${ }^{2,3 *}$, dan Sobir $^{2,3}$ \\ ${ }^{1}$ Program Studi Pemuliaan dan Bioteknologi Tanaman, Sekolah Pascasarjana, Institut Pertanian Bogor \\ ${ }^{2}$ Departemen Agronomi dan Hortikultura, Fakultas Pertanian, Institut Pertanian Bogor \\ (Bogor Agricultural University), Jl. Meranti, Kampus IPB Darmaga, Bogor 16680, Indonesia \\ ${ }^{3}$ Pusat Kajian Hortikultura Tropika, Institut Pertanian Bogor, Kampus IPB Baranangsiang \\ Jl. Raya Pajajaran Bogor 16141, Indonesia
}

Diterima 2 Mei 2019/Disetujui 15 Oktober 2019

\begin{abstract}
Increasingly limited land in the high elevation and increasing of global temperature needed breeding of cauliflower plants originating from temperate regions to be adaptively planted in low elevation. This study aimed to identify the morphological variability and yield component of cauliflower planted in the high elevation and low elevation. The experiment was conducted in Pasir Sarongge (1,117 m asl) and Tajur II (340 m asl) from June to December 2016. This experiment was conducted with a randomized complete block design single-factor (12 genotypes of cauliflower) with three replications. The results showed that $B O B 021$ genotype was not flowering in Tajur. Qualitative characteristics that are stable in two locations include leaf attitude, leaf color, curd color, leaf lobing, and curd covering by inner leaves. Vegetative characters and yields in low elevation were higher than high elevation, time of flowering and harvesting in high elevation was earlier than in low elevation. Based on the correlation analysis, an increase in the yield characters can be seen from the increase in vegetative character and increase in longevity time of flowering and harvesting.
\end{abstract}

Keywords: correlation, flowering, qualitative, quantitative

\section{ABSTRAK}

Keterbatasan lahan di dataran tinggi dan peningkatan suhu globalmenyebabkan perlunya pemuliaan untukmenghasilkan kubis bunga yang berasal dari wilayah temperate menjadi adaptif ditanam di dataran rendah tropis. Percobaan bertujuan mengidentifikasi keragaman morfologi dan komponen hasil kubis bunga yang ditanam di dataran tinggi dan dataran rendah. Percobaan dilaksanakan di KP Pasir Sarongge (1,117 m dpl) dan KP Tajur II (340 m dpl) dari Juni sampai Desember 2016. Percobaan menggunakan rancangan kelompok lengkap teracak faktor tunggal (12 genotipe kubis bunga) dengan tiga ulangan. Hasil percobaan menunjukkan bahwa genotipe BOB 021 tidak berbunga di Tajur. karakter kualitatif yang stabil di dua lokasi diantaranya perilaku daun, warna daun, warna bunga, kerutan daun, dan bunga tertutupi daun. Karakter vegetatif dan hasil pada dataran rendah lebih tinggi dibandingkan dataran tinggi, umur berbunga dan umur panen lebih cepat di dataran tinggi dibandingkan dataran rendah. Peningkatan karakter hasil berkorelasi dengan peningkatan karakter vegetatif, peningkatan umur berbunga, dan umur panen.

Kata kunci: korelasi, kualitatif, kuantitatif, pembungaan

\section{PENDAHULUAN}

Kubis bunga (Brassica oleracea var. botrytis L.) atau yang dikenal dengan bunga kol, kembang kol, atau cauliflower merupakan tanaman semusim yang memiliki

\footnotetext{
*Penulis untuk korespondensi. e-mail: dardaefendi@gmail.com
}

banyak manfaat dan menjadi tanaman penting dari famili Brassicaceae. Kesadaran masyarakat akan hidup sehat memicu tingginya permintaaan akan sayuran ini. Tanaman kubis bunga terus mengalami peningkatan produksi setiap tahunnya. Produktivitas kubis bunga dan brokoli di dunia mencapai 17.81 ton ha ${ }^{-1}$ pada 2013 (FAO, 2015), sementara produktivitas kubis bunga di Indonesia hanya sebesar 12.08 ton ha ${ }^{-1}$ pada tahun 2014 (BPS, 2015). 
Italia secara umum diketahui sebagai daerah asal dari brokoli dan kubis bunga (Quiros dan Farnham, 2011). Daerah asal kubis bunga yang merupakan wilayah temperate menyebabkan penanaman kubis bunga di wilayah tropis terkonsentrasi di dataran tinggi. Sentra produksi kubis bunga di Indonesia berada pada wilayah dataran tinggi yaitu pada ketinggian 1,000-2,000 m dpl, seperti di Jawa Barat (Lembang, Cianjur, Garut, Subang, Cisarua, Cibodas), Jawa Tengah (Kopeng), dan Bali (Bedugul) (Kementan, 2017).

Keterbatasan lahan di dataran tinggi dan peningkatan suhu (global warming) menyebabkan perlunya pemuliaan untuk menghasilkan kubis bunga yang adaptif di dataran rendah. Suhu lebih dari $22{ }^{\circ} \mathrm{C}$ diketahui dapat menghambat pembentukan bunga pada beberapa kultivar kubis bunga (Hasan et al., 2016). Suhu tinggi merupakan salah satu cekaman abiotik yang berpengaruh dalam membatasi pertumbuhan, perkembangan, dan produksi suatu tanaman. Tanaman yang memiliki toleransi terhadap suhu tinggi dapat menjadi indikasi bahwa tanaman tersebut dapat ditanam di dataran rendah. Pemuliaan tanaman telah menghasilkan beberapa tanaman toleran terhadap suhu tinggi, seperti pada Arabidopsis (Zhang et al., 2016), padi (Shah dan Nahakpam, 2012), dan gandum (Mondal et al., 2016). Penelitian kubis bunga dengan menggunakan varietas toleran dataran rendah juga telah banyak dilakukan, seperti pada penelitian Gomies et al. (2012). Penelitian ini bertujuan mengidentifikasi keragaman morfologi dan komponen hasil kubis bunga koleksi Pusat Kajian Hortikultura Tropika (PKHT) berdasarkan perbedaan lokasi penanaman, yaitu dataran tinggi (optimum) dan dataran rendah (suboptimum).

\section{BAHAN DAN METODE}

Percobaan dilaksanakan di dua lokasi yaitu Kebun Percobaan Pasir Sarongge, Cianjur dengan ketinggian 1,117 m dpl (dataran tinggi) pada Juni sampai Desember 2016 dan Kebun Percobaan Tajur II, Bogor dengan ketinggian 340 m dpl (dataran rendah) pada Juli sampai Desember 2016. Materi genetik yang digunakan adalah 12 genotipe kubis bunga koleksi PKHT IPB, yang terdiri atas BOB 001, BOB 002, BOB 003, BOB 013, dan BOB 014 (varietas introduksi); BOB 004, BOB 016, BOB 017, BOB 018, BOB 019, dan BOB 020 (varietas komersil); dan BOB 021 (varietas lokal). Percobaan dilakukan dalam rancangan kelompok lengkap teracak (RKLT) dengan tiga ulangan di tiap lokasi, yang setiap satuan percobaan terdiri atas 20 tanaman.

Persemaian menggunakan tray dengan media tanam tanah:pupuk kandang:sekam (1:1:1). Bibit dipindah tanamkan di lahan setelah berumur 3-4 minggu (4-5 helai daun) dengan jarak tanam $60 \mathrm{~cm} \times 40 \mathrm{~cm}$ (Hossain et al., 2011). Pemupukan pertama terdiri atas Urea 5 g, SP-36 5 $\mathrm{g}$, dan $\mathrm{KCl} 5 \mathrm{~g}$ per tanaman yang diaplikasikan $<1$ minggu setelah tanam (MST). Pemupukan selanjutnya terdiri atas Urea $5 \mathrm{~g}$, SP-36 $5 \mathrm{~g}, \mathrm{KCl} 5 \mathrm{~g}$, dan NPK (16:16:16) 5 g per tanaman yang diaplikasikan pada 3 MST, 6 MST, dan kelipatan seterusnya hingga panen. Plastik sungkup transparan dipasang sepanjang bedengan saat tanaman berumur 1-2 MST (sebelum memasuki masa generatif) sampai panen. Kubis bunga dipanen saat bunga sudah padat dan kompak.

Pengamatan morfologi yang diamati berdasarkan IBPGR (1990) dan UPOV (2009). Pengamatan karakter kuantitatif terdiri atas tinggi tanaman, diameter tanaman, rasio lebar per panjang daun, jumlah daun, umur berbunga, umur panen, bobot panen, diameter bunga, dan rasio bobot panen per bobot total tanaman. Pengamatan karakter kualitatif terdiri atas karakter tanaman (perilaku daun); karakter daun (lobing pada daun, warna daun (dengan lapisan lilin jika ada), intensitas warna daun, lekukan pada ujung daun, bentuk daun, lepuhan daun, kerutan dekat tulang daun utama, dan gelombang pada tepi daun); karakter bunga (bunga tertutupi daun, bentuk bunga secara longitudinal, bentuk kubah pada bunga, warna bunga, tonjolan bunga, dan tekstur bunga). Analisis data yang digunakan adalah analisis ragam dengan uji lanjut menggunakan BNJ (Beda Nyata Jujur) pada taraf 5\% menggunakan software STAR 2.0.1; analisis korelasi menggunakan software STAR 2.0.1; dan analisis gerombol dengan metode Gower dan metode pengelompokan average linkage menggunakan R 3.1.1.

\section{HASIL DAN PEMBAHASAN}

\section{Pengaruh Suhu terhadap Pembungaan}

Hasil percobaan menunjukkan bahwa dari seluruh genotipe yang diuji, hanya genotipe BOB 021 yang tidak berbunga di dataran rendah. BOB 021 membutuhkan suhu lebih rendah dibandingkan genotipe lainnya. Wahid et al. (2007) menyatakan bahwa suhu rata-rata merupakan kriteria yang paling tepat digunakan sebagai penentu respon tanaman terhadap suhu tinggi. Suhu saat pembungaan pada penelitian berdasarkan BMKG (2017) di dataran tinggi berkisar antara $21.30-22.50{ }^{\circ} \mathrm{C}$ dan suhu saat pembungaan di dataran rendah berkisar antara $26.00-26.20^{\circ} \mathrm{C}$. Genotipe BOB 001, BOB 002, BOB 003, BOB 004, BOB 013, BOB 014, BOB 016, BOB 017, BOB 018, BOB 019, dan BOB 020 dapat berbunga pada suhu $21.30-26.20^{\circ} \mathrm{C}$.

Wahid et al. (2007) menyatakan bahwa batas atas suhu (threshold) Brassica untuk dapat berbunga adalah 29 ${ }^{\circ} \mathrm{C}$. Akan tetapi pada penelitian ini menunjukkan bahwa genotipe BOB 021 sudah tidak berbunga pada kisaran suhu $26{ }^{\circ} \mathrm{C}$. Genotipe BOB 021 berbunga pada suhu 21.30 ${ }^{\circ} \mathrm{C}$. Olesen dan Grevsen (1993) menyatakan bahwa setiap kultivar memiliki batas minimum dan maksimum terhadap suhu yang diperlukan untuk induksi pembungaan. Driedonks et al. (2016) juga menyatakan bahwa kisaran suhu optimum suatu tanaman mengakibatkan sensitivitas terhadap suhu tinggi bervariasi antara jenis tanaman, spesies, dan kultivar.

\section{Karakter Kualitatif Kubis Bunga}

Percobaan ini menunjukkan bahwa faktor lingkungan (perbedaan lokasi) sangat mempengaruhi perbedaan karakter kualitatif tanaman kubis bunga. Perbedaan lingkungan berupa perbedaan suhu sangat mempengaruhi penampilan dan memiliki peran yang penting terhadap kualitas tanaman 
kubis bunga. Olesen dan Grevsen (1993) menyatakan bahwa perubahan suhu dapat menurunan kualitas produk. Berdasarkan 15 karakter yang diamati, terdapat 5 karakter kualitatif yang stabil di dua lokasi diantaranya perilaku daun, warna daun, warna bunga, kerutan daun, dan bunga tertutupi daun. Genotipe yang memiliki kestabilan kualitatif berdasarkan karakter daun adalah BOB 001 dan BOB 002. Genotipe yang memiliki kestabilan kualitatif berdasarkan karakter bunga adalah BOB 002 dan BOB 003.

\section{Karakter Kuantitatif Fase Vegetatif Kubis Bunga}

Hasil analisis sidik ragam dua lokasi pada taraf 5\% menunjukkan bahwa faktor genotipe berpengaruh sangat nyata pada seluruh karakter morfologi yang diamati (Tabel 1). Karakter tinggi tanaman di dataran tinggi menunjukkan bahwa BOB 021 dan BOB 004 memiliki nilai tertinggi sebesar $68.50 \mathrm{~cm}$ dan $67.29 \mathrm{~cm}$ (Tabel 2). Genotipe BOB 021 memiliki nilai tertinggi sebesar $75.58 \mathrm{~cm}$ yang tidak berbeda nyata dengan BOB 004 sebesar $71.00 \mathrm{~cm}$ di dataran rendah. Karakter diameter tanaman menunjukkan bahwa BOB 021 memiliki nilai paling besar dibandingkan genotipe lainnya pada kedua lokasi, yaitu $91.38 \mathrm{~cm}$ (dataran tinggi) dan $109.31 \mathrm{~cm}$ (dataran rendah). Diameter tanaman yang paling kecil dibandingkan genotipe lainnya pada dataran tinggi adalah BOB 002 sebesar $40.93 \mathrm{~cm}$, yang tidak berbeda nyata dengan BOB 001 dan BOB 003 sebesar $44.43 \mathrm{~cm}$ dan $46.64 \mathrm{~cm}$. Diameter tanaman yang paling kecil pada dataran rendah adalah BOB 001, BOB 013, BOB 014, dan BOB 020 sebesar $66.52 \mathrm{~cm}, 67.47 \mathrm{~cm}, 65.22 \mathrm{~cm}$, dan $66.56 \mathrm{~cm}$.

Rasio lebar per panjang daun merupakan karakter vegetatif yang menunjukkan bahwa keragaan di dataran

Tabel 1. Rekapitulasi hasil sidik ragam karakter kuantitatif kubis di dataran tinggi dan dataran rendah

\begin{tabular}{lllrr}
\hline \multirow{2}{*}{ Karakter } & \multicolumn{2}{c}{ Genotipe } & \multicolumn{2}{c}{ KK (\%) } \\
\cline { 2 - 5 } & DT & DR & DT & DR \\
\hline Tinggi tanaman & $* *$ & $* *$ & 6.30 & 3.83 \\
Diameter tanaman & $* *$ & $* *$ & 7.87 & 5.50 \\
Rasio lebar per panjang daun & $* *$ & $* *$ & 4.15 & 5.07 \\
Jumlah daun & $* *$ & $* *$ & 6.54 & 4.37 \\
Umur berbunga & $* *$ & $* *$ & 0.41 & 3.96 \\
Umur panen & $* *$ & $* *$ & 1.30 & 3.53 \\
Bobot panen & $* *$ & $* *$ & 16.33 & 19.46 \\
Diameter bunga & $* *$ & $* *$ & 10.43 & 7.94 \\
Bobot panen per bobot total tanaman & $* *$ & $* *$ & 8.09 & 14.85
\end{tabular}

Keterangan: DT = dataran tinggi; $\mathrm{DR}=$ dataran rendah; $\mathrm{KK}=$ koefisien keragaman; **bepengaruh sangat nyata; *berpengaruh nyata; tn tidak berpengaruh nyata pada taraf $5 \%$

Tabel 2. Tinggi tanaman, diameter tanaman, rasio lebar per panjang daun, dan jumlah daun pada kubis bunga di dua lokasi

\begin{tabular}{lllllllll}
\hline \multirow{2}{*}{ Genotipe } & \multicolumn{2}{c}{ TT $(\mathrm{cm})$} & \multicolumn{2}{c}{ DiT $(\mathrm{cm})$} & \multicolumn{2}{c}{ RD } & \multicolumn{1}{c}{ JD } \\
\cline { 2 - 8 } & \multicolumn{1}{c}{ DT } & \multicolumn{1}{c}{ DR } & \multicolumn{1}{c}{ DT } & DR & DT & DR & DT & DR \\
\hline BOB 001 & $32.95 \mathrm{de}$ & $49.11 \mathrm{ef}$ & $44.43 \mathrm{ef}$ & $66.52 \mathrm{~d}$ & $0.50 \mathrm{bc}$ & $0.44 \mathrm{abc}$ & $16.0 \mathrm{bcd}$ & $18.5 \mathrm{ab}$ \\
BOB 002 & $29.39 \mathrm{e}$ & $50.60 \mathrm{ef}$ & $40.93 \mathrm{f}$ & $72.96 \mathrm{~cd}$ & $0.56 \mathrm{a}$ & $0.46 \mathrm{a}$ & $15.5 \mathrm{bcd}$ & $19.0 \mathrm{ab}$ \\
BOB 003 & $34.38 \mathrm{de}$ & $50.48 \mathrm{ef}$ & $46.64 \mathrm{ef}$ & $72.31 \mathrm{~cd}$ & $0.52 \mathrm{ab}$ & $0.46 \mathrm{ab}$ & $13.7 \mathrm{cde}$ & $19.3 \mathrm{ab}$ \\
BOB 004 & $67.29 \mathrm{a}$ & $71.00 \mathrm{ab}$ & $84.59 \mathrm{ab}$ & $102.29 \mathrm{a}$ & $0.45 \mathrm{~cd}$ & $0.44 \mathrm{abc}$ & $17.0 \mathrm{~b}$ & $19.9 \mathrm{ab}$ \\
BOB 013 & $48.18 \mathrm{bc}$ & $50.15 \mathrm{ef}$ & $65.48 \mathrm{~cd}$ & $67.47 \mathrm{~d}$ & $0.43 \mathrm{~d}$ & $0.46 \mathrm{ab}$ & $15.7 \mathrm{bcd}$ & $18.4 \mathrm{ab}$ \\
BOB 014 & $50.36 \mathrm{~b}$ & $49.41 \mathrm{ef}$ & $62.50 \mathrm{~cd}$ & $65.22 \mathrm{~d}$ & $0.44 \mathrm{~d}$ & $0.46 \mathrm{ab}$ & $15.0 \mathrm{bcde}$ & $18.1 \mathrm{~b}$ \\
BOB 016 & $47.66 \mathrm{bc}$ & $61.23 \mathrm{~cd}$ & $68.62 \mathrm{~cd}$ & $84.99 \mathrm{bc}$ & $0.41 \mathrm{~d}$ & $0.43 \mathrm{abc}$ & $17.4 \mathrm{ab}$ & $19.8 \mathrm{ab}$ \\
BOB 017 & $52.66 \mathrm{~b}$ & $62.04 \mathrm{~cd}$ & $71.50 \mathrm{bc}$ & $82.53 \mathrm{bc}$ & $0.42 \mathrm{~d}$ & $0.40 \mathrm{bc}$ & $16.6 \mathrm{bc}$ & $20.1 \mathrm{ab}$ \\
BOB 018 & $48.91 \mathrm{bc}$ & $66.52 \mathrm{bc}$ & $63.61 \mathrm{~cd}$ & $86.50 \mathrm{~b}$ & $0.44 \mathrm{~d}$ & $0.43 \mathrm{abc}$ & $14.9 \mathrm{bcde}$ & $18.0 \mathrm{~b}$ \\
BOB 019 & $40.46 \mathrm{~cd}$ & $55.52 \mathrm{de}$ & $56.67 \mathrm{de}$ & $76.34 \mathrm{bcd}$ & $0.44 \mathrm{~d}$ & $0.43 \mathrm{abc}$ & $13.4 \mathrm{de}$ & $20.7 \mathrm{a}$ \\
BOB 020 & $37.25 \mathrm{de}$ & $48.88 \mathrm{f}$ & $57.30 \mathrm{cde}$ & $66.56 \mathrm{~d}$ & $0.46 \mathrm{~cd}$ & $0.44 \mathrm{abc}$ & $12.0 \mathrm{e}$ & $18.5 \mathrm{ab}$ \\
BOB 021 & $68.50 \mathrm{a}$ & $75.58 \mathrm{a}$ & $91.38 \mathrm{a}$ & $109.31 \mathrm{a}$ & $0.40 \mathrm{~d}$ & $0.39 \mathrm{c}$ & $20.2 \mathrm{a}$ & $18.6 \mathrm{ab}$ \\
\hline
\end{tabular}

Keterangan: Angka-angka yang sama pada kolom untuk tiap karakter tidak berbeda nyata pada uji BNJ taraf 5\%; DT = dataran tinggi; dan $\mathrm{DR}=$ dataran rendah; $\mathrm{TT}=$ tinggi tanaman; $\mathrm{DiT}=$ diameter tanaman; $\mathrm{RD}=$ rasio lebar per panjang daun; $\mathrm{JD}=$ jumlah daun 
tinggi lebih tinggi dibandingkan di dataran rendah. Rasio lebar per panjang daun kubis bunga pada penelitian ini menunjukkan rasio $>0.40$. Tian et al. (2017) menyatakan bahwa rasio daun (lebar per panjang daun) berhubungan dengan bentuk daun pada Brassica napus. Jian et al. (2017) juga menyatakan bahwa ukuran daun memiliki hubungan dengan agronomi tanaman, seperti hasil dan kualitas tanaman Brassica rapa.

Karakter jumlah daun diamati saat tanaman telah memasuki fase generatif, kecuali BOB 021 pada dataran rendah yang diamati saat pertumbuhan maksimal. Jumlah daun di dataran rendah lebih banyak dibandingkan di dataran tinggi, kecuali BOB 021. Gomies et al. (2012) menyatakan bahwa jumlah daun memiliki korelasi positif dengan luas daun tanaman kubis bunga, yang berpengaruh terhadap efisiensi penangkapan cahaya untuk proses fotosintesis. Wurr dan Fellows (2000) menyatakan bahwa jumlah daun minimum pada akhir fase vegetatif adalah 10 helai. Pada percobaan ini jumlah daun terendah di dataran tinggi sebanyak 12 helai dan di dataran rendah sebanyak 18 helai. Hasan et al. (2016) menyatakan bahwa jumlah daun selain dipengaruhi faktor genotipe juga dipengaruhi oleh faktor lingkungan.

Hasil percobaan ini menunjukkan bahwa keragaan vegetatif tanaman di dataran rendah lebih besar dibandingkan tanaman di dataran tinggi. Adanya perbedaan respon genotipe dengan lingkungan menunjukkan bahwa suatu genotipe memiliki adaptasi spesifik terhadap lingkungan yang diuji (Trustinah dan Iswanto, 2013) dan memiliki pola respon yang berbeda terhadap perubahan kondisi lingkungan (Sundari et al., 2016). Keragaan vegetatif di dataran rendah lebih besar dapat terjadi karena fase vegetatif yang lebih panjang di dataran rendah. Pembentukan daun dan fase vegetatif akan terus berlanjut jika induksi pembungaan tidak terjadi. Penelitian Marliah et al. (2013) juga menunjukkan bahwa adanya keragaman tinggi tanaman dan jumlah daun pada kubis bunga.

\section{Karakter Kuantitatif Fase Generatif Kubis Bunga}

Karakter generatif dianalisis tanpa melibatkan BOB 021. Amasino (2010) menyatakan bahwa inisiasi pembungaan merupakan titik kritis dalam siklus tanaman untuk memasuki fase generatif, lingkungan yang memiliki pengaruh besar yaitu perubahan suhu maupun panjang hari. BOB 001, BOB 002, dan BOB 003 memiliki umur berbunga lebih genjah di dataran tinggi yaitu 33 HST; sedangkan pada dataran rendah dimiliki BOB 001, BOB 003, dan BOB 020 yaitu 38-39 HST. BOB 016 dan BOB 018 memiliki umur berbunga lebih lama di dataran tinggi yaitu 59 HST; sedangkan di dataran rendah dimiliki BOB 004, BOB 016, dan BOB 018 yaitu 59-61 HST. Lamanya umur berbunga hingga umur panen kubis bunga pada penelitian ini berkisar antara 10-13 hari, dari seluruh genotipe yang diuji.

Karakter umur berbunga dan umur panen pada tanaman kubis bunga berdasarkan lokasi penanaman menunjukkan bahwa umur berbunga dan umur panen di dataran tinggi lebih cepat pada beberapa genotipe (BOB
016, BOB 017, BOB 018, dan BOB 019) dibandingkan di dataran rendah, kecuali genotipe BOB 020 memiliki umur berbunga lebih cepat di dataran rendah dibandingkan di dataran tinggi (Tabel 3). Suhu rendah yang selalu tersedia di dataran tinggi menyebabkan tanaman yang memiliki kondisi sesuai akan segera berbunga, berbeda dengan penanaman di dataran rendah dengan suhu yang lebih tinggi menyebabkan tanaman terus tumbuh secara vegetatif sampai mendapatkan kondisi yang sesuai untuk induksi pembungaan. Penelitian Widiatningrum dan Pukan (2010) juga menunjukkan bahwa kubis bunga yang ditanam di dataran tinggi memiliki waktu inisiasi pembungaan yang lebih cepat dibandingkan di dataran rendah. Uptmoor et al. (2012) menyatakan bahwa vernalisasi berhubungan dengan keragaman umur berbunga dalam suatu genotipe. Penelitian $\mathrm{Xu}$ et al. (2015) juga mengungkapkan bahwa umur pembungaan sangat dipengaruhi oleh lingkungan, penanaman Brassica napus di beberapa lokasi memiliki keragaman yang tinggi, dan penanaman genotipe pada lokasi yang sama dengan perbedaan tahun juga memiliki keragaman yang tinggi.

Hasil pengamatan terhadap hasil dari karakter generatif, seperti bobot panen dan diameter bunga menunjukkan bahwa keragaan tanaman di dataran rendah lebih tinggi dibandingkan dengan keragaan tanaman di dataran tinggi (Tabel 3). Bobot panen tertinggi diperoleh dari genotipe BOB 004 di kedua lokasi sebesar $851.56 \mathrm{~g}$ (dataran tinggi) dan 1,076 g (dataran rendah). Diameter bunga pada umumnya dalam penelitian ini di dataran tinggi lebih kecil dibandingkan di dataran rendah. Diameter bunga yang terbesar pada dataran tinggi diperoleh BOB 016 sebesar $16.42 \mathrm{~cm}$; sedangkan di dataran rendah diameter terbesar diperoleh genotipe BOB 004 sebesar $21.98 \mathrm{~cm}$.

Karakter rasio bobot panen per bobot total tanaman di dataran tinggi menunjukkan bahwa BOB 018 memiliki nilai tertinggi sebesar 0.75 , sedangkan di dataran rendah dimiliki BOB 001 dan BOB 020 sebesar 0.61 meskipun tidak berbeda nyata berdasarkan analisis ragam. Rasio bobot panen per bobot total tanaman pada genotipe BOB 004, BOB 016, BOB 017, BOB 018, dan BOB 019 memiliki rasio lebih tinggi saat ditanam di dataran tinggi dibanding di dataran rendah. Semakin tinggi rasio bobot panen per bobot total tanaman menunjukkan akumulasi hara yang tertuju pada hasil semakin efisien. Berdasarkan rasio bobot panen per bobot total tanaman menunjukkan bahwa penanaman di dataran tinggi lebih baik dibandingkan di dataran rendah. Genotipe yang memiliki nilai rasio bobot panen per bobot total tanaman $>0.50$ yang stabil di dua lokasi adalah BOB 001, BOB 002, BOB 003, BOB 013, BOB 014, BOB 016, dan $\mathrm{BOB}$ 020. Pada genotipe yang memiliki rasio $>0.50$ tersebut menunjukkan bahwa bobot panen yang dihasilkan melebihi separuh dari bobot total tanamannya.

\section{Korelasi Antarkarakter Kuantitatif}

Korelasi merupakan derajat keeratan hubungan satu karakter dengan karakter lainnya (Safuan et al., 2014). Analisis korelasi antarkarakter kuantitatif dianalisis per lokasi yang ditunjukkan pada Tabel 4. Karakter yang 
Tabel 3. Umur berbunga, umur panen, bobot panen, diameter bunga, dan rasio bobot panen/bobot total kubis bunga di dua lokasi

\begin{tabular}{|c|c|c|c|c|c|c|c|c|c|c|}
\hline \multirow{2}{*}{ Genotipe } & \multicolumn{2}{|c|}{ UB (HST) } & \multicolumn{2}{|c|}{ UP (HST) } & \multicolumn{2}{|c|}{$\mathrm{BP}(\mathrm{g})$} & \multicolumn{2}{|c|}{ DB $(\mathrm{cm})$} & \multicolumn{2}{|c|}{ BPBT } \\
\hline & DT & DR & DT & DR & DT & DR & DT & DR & DT & DR \\
\hline BOB 001 & $33 \mathrm{~h}$ & $38 \mathrm{e}$ & $43 \mathrm{f}$ & $49 c$ & $248.89 \mathrm{de}$ & $558.58 \mathrm{bc}$ & $11.69 \mathrm{bcde}$ & $15.41 \mathrm{~b}$ & $0.61 \mathrm{ab}$ & $0.61 \mathrm{a}$ \\
\hline BOB 002 & $33 \mathrm{~h}$ & $43 \mathrm{de}$ & $43 \mathrm{f}$ & $54 \mathrm{c}$ & $230.22 \mathrm{de}$ & $650.33 b c$ & $10.38 \mathrm{de}$ & $16.80 \mathrm{~b}$ & $0.63 a b$ & $0.59 \mathrm{a}$ \\
\hline BOB 003 & $33 \mathrm{~h}$ & $39 \mathrm{e}$ & $46 e$ & $52 \mathrm{c}$ & $171.67 \mathrm{e}$ & $631.96 \mathrm{bc}$ & $9.33 \mathrm{e}$ & $17.38 \mathrm{~b}$ & $0.58 \mathrm{~b}$ & $0.54 \mathrm{a}$ \\
\hline BOB 004 & $47 \mathrm{c}$ & $61 \mathrm{a}$ & $57 \mathrm{bc}$ & $72 a$ & $851.56 a$ & $1,076.32 \mathrm{a}$ & $15.66 \mathrm{ab}$ & $21.98 \mathrm{a}$ & $0.57 \mathrm{~b}$ & $0.42 \mathrm{a}$ \\
\hline BOB 013 & $40 \mathrm{f}$ & $51 \mathrm{~b}$ & $50 \mathrm{~d}$ & $62 b$ & $532.22 \mathrm{bc}$ & $469.78 \mathrm{c}$ & 13.98abcd & $16.89 \mathrm{~b}$ & $0.58 \mathrm{~b}$ & $0.55 \mathrm{a}$ \\
\hline BOB 014 & $37 \mathrm{~g}$ & $47 \mathrm{bcd}$ & $50 \mathrm{~d}$ & $62 b$ & $428.89 \mathrm{~cd}$ & $485.56 \mathrm{bc}$ & 13.07abcde & $18.25 \mathrm{ab}$ & $0.56 \mathrm{~b}$ & $0.58 \mathrm{a}$ \\
\hline BOB 016 & $59 a$ & $59 a$ & $72 \mathrm{a}$ & $73 a$ & $705.83 \mathrm{ab}$ & $855.00 \mathrm{abc}$ & $16.42 \mathrm{a}$ & $19.00 \mathrm{ab}$ & $0.68 \mathrm{ab}$ & $0.55 \mathrm{a}$ \\
\hline BOB 017 & $49 b$ & $49 b c$ & $59 b$ & $62 b$ & $577.30 \mathrm{bc}$ & $682.10 \mathrm{bc}$ & 14.86abc & 19.17ab & $0.64 a b$ & $0.40 \mathrm{a}$ \\
\hline ВOB 018 & $59 a$ & $60 \mathrm{a}$ & $72 \mathrm{a}$ & $73 a$ & $623.79 \mathrm{bc}$ & $862.94 \mathrm{ab}$ & $15.00 \mathrm{abc}$ & $18.45 \mathrm{ab}$ & $0.75 \mathrm{a}$ & $0.45 \mathrm{a}$ \\
\hline ВОВ 019 & $45 d$ & $45 \mathrm{~cd}$ & $56 \mathrm{c}$ & $55 \mathrm{c}$ & $245.00 \mathrm{de}$ & $551.67 \mathrm{bc}$ & $10.70 \mathrm{de}$ & $19.50 \mathrm{ab}$ & $0.66 \mathrm{ab}$ & $0.48 \mathrm{a}$ \\
\hline BOB 020 & $42 \mathrm{e}$ & $39 \mathrm{e}$ & $52 \mathrm{~d}$ & $51 \mathrm{c}$ & $215.56 \mathrm{e}$ & $564.81 \mathrm{bc}$ & $11.56 \mathrm{cde}$ & $16.30 \mathrm{~b}$ & $0.67 \mathrm{ab}$ & $0.61 \mathrm{a}$ \\
\hline
\end{tabular}

Keterangan: Angka-angka yang diikuti huruf yang sama pada kolom untuk tiap karakter tidak berbeda nyata pada uji BNJ taraf 5\%; DT = dataran tinggi; dan $\mathrm{DR}=$ dataran rendah; $\mathrm{UB}=$ umur berbunga; $\mathrm{UP}=$ umur panen; $\mathrm{BP}=$ bobot panen; $\mathrm{DB}=$ diameter bunga; $\mathrm{BPBT}=$ rasio bobot panen per bobot total tanaman

stabil memiliki korelasi positif di dua lokasi penelitian berdasarkan umur berbunga adalah diameter tanaman, umur panen, bobot panen, dan diameter bunga. Peningkatan umur berbunga (umur berbunga lama) berkorelasi positif dengan meningkatnya diameter tanaman, umur panen, bobot panen, dan diameter bunga; begitu juga sebaliknya. Umur berbunga yang cepat memiliki umur panen yang cepat, keragaan diameter tanaman, bobot panen, dan diameter bunga yang rendah. Cervenski et al. (2012) menyatakan bahwa kubis dengan umur panen lama, memiliki volume panen dan berat panen yang lebih besar dibandingkan kubis yang memiliki umur panen cepat.

Bobot panen memiliki korelasi positif stabil di dua lokasi dengan karakter tinggi tanaman, diameter tanaman, umur berbunga, umur panen, dan diameter bunga.
Peningkatan bobot panen dapat diamati dari peningkatan karakter vegetatif (tinggi tanaman dan diameter tanaman) dan peningkatan karakter generatif (umur berbunga, umur panen, dan diameter bunga). Hasil yang tinggi memerlukan umur berbunga dan panen yang lebih lama, serta keragaan vegetatif yang lebih besar. Kibar et al. (2016) menyatakan bahwa tinggi tanaman, diameter tanaman, bobot panen, diameter dan panjang kepala kubis merupakan komponen utama pada tanaman kubis.

\section{Pengelompokan Genotipe}

Hasil analisis gerombol berdasarkan karakter morfologi (kualitatif dan kuantitatif) di dua lokasi penelitian dapat dilihat pada Gambar 1. Pengelompokan dilakukan di

Tabel 4. Analisis korelasi pada kubis bunga di dua lokasi

\begin{tabular}{|c|c|c|c|c|c|c|c|c|c|}
\hline & TT & DiT & $\mathrm{RD}$ & JD & UB & UP & $\mathrm{BP}$ & DB & BPBT \\
\hline $\mathrm{TT}$ & & $0.97 * *$ & $-0.58 \mathrm{tn}$ & $0.38 \mathrm{tn}$ & $0.85 * *$ & $0.82 * *$ & $0.90 * *$ & $0.83 * *$ & $-0.84 * *$ \\
\hline DiT & $0.97 * *$ & & $-0.46 \mathrm{tn}$ & $0.48 \mathrm{tn}$ & $0.79 * *$ & $0.74 * *$ & $0.95 * *$ & $0.86^{* *}$ & $-0.79 * *$ \\
\hline $\mathrm{RD}$ & $-0.70^{*}$ & $-0.78 * *$ & & $-0.50 \mathrm{tn}$ & $-0.29 \mathrm{tn}$ & $-0.29 \mathrm{tn}$ & $-0.34 \mathrm{tn}$ & $-0.38 \mathrm{tn}$ & $0.65^{*}$ \\
\hline JD & $0.50 \mathrm{tn}$ & $0.45 \mathrm{tn}$ & $-0.24 \mathrm{tn}$ & & $0.11 \mathrm{tn}$ & $0.06 \mathrm{tn}$ & $0.29 \mathrm{tn}$ & $0.60^{*}$ & $-0.52 \mathrm{tn}$ \\
\hline UB & $0.56 \mathrm{tn}$ & $0.66^{*}$ & $-0.73^{*}$ & $0.31 \mathrm{tn}$ & & $0.98 * *$ & $0.74 * *$ & $0.72 *$ & $-0.61 *$ \\
\hline UP & $0.53 \mathrm{tn}$ & $0.61 *$ & $-0.72 *$ & $0.29 \mathrm{tn}$ & $0.99 * *$ & & $0.72 *$ & $0.69^{*}$ & $-0.58 \mathrm{tn}$ \\
\hline BP & $0.90 * *$ & $0.90 * *$ & $-0.65^{*}$ & $0.72 *$ & $0.72 *$ & $0.69 *$ & & $0.71 *$ & $-0.59 *$ \\
\hline DB & $0.81^{* *}$ & $0.85 * *$ & $-0.73 * *$ & $0.69^{*}$ & $0.79 * *$ & $0.75 * *$ & $0.95 * *$ & & $-0.80 * *$ \\
\hline BPBT & $-0.14 \mathrm{tn}$ & $-0.02 \mathrm{tn}$ & $-0.23 \mathrm{tn}$ & $-0.16 \mathrm{tn}$ & $0.69 *$ & $0.69 *$ & $0.08 \mathrm{tn}$ & $0.22 \mathrm{tn}$ & \\
\hline
\end{tabular}

Keterangan: Diagonal kiri = korelasi di dataran tinggi; diagonal kanan $=$ korelasi di dataran rendah *berkorelasi nyata; $* *$ berkorelasi sangat nyata; $\mathrm{tn}=$ tidak berkorelasi nyata pada taraf 5\% berdasarkan metode Pearson; TT = tinggi tanaman; DiT $=$ diameter tanaman; $\mathrm{RD}=$ rasio lebar per panjang daun; $\mathrm{JD}=$ jumlah daun; $\mathrm{UB}=$ umur berbunga; $\mathrm{UP}=$ umur panen; $\mathrm{BP}=$ bobot panen; $\mathrm{DB}=$ diameter bunga; BPBT = rasio bobot panen per bobot total tanaman 
masing-masing lokasi tanpa melibatkan genotipe BOB 021 . Pengelompokan berdasarkan koefisien ketidakmiripan $40 \%$ (kemiripan 60\%) pada kedua lokasi membagi genotipe menjadi 3 kelompok, yaitu kelompok I, IIa, dan IIb. Genotipe yang stabil mengelompok di kedua lokasi, diantaranya kelompok I yaitu BOB 004; kelompok IIa terdiri atas BOB 013, BOB 014, dan BOB 017; dan kelompok IIb terdiri atas BOB 001, BOB 002, BOB 003, dan BOB 020.

Berdasarkan hasil pengamatan kuantitatif, kelompok I merupakan kelompok genotipe yang memiliki keragaan vegetatif besar, bobot panen besar, dan umur panen yang lama. Kelompok IIa merupakan kelompok genotipe yang memiliki keragaan vegetatif sedang, bobot panen sedang,

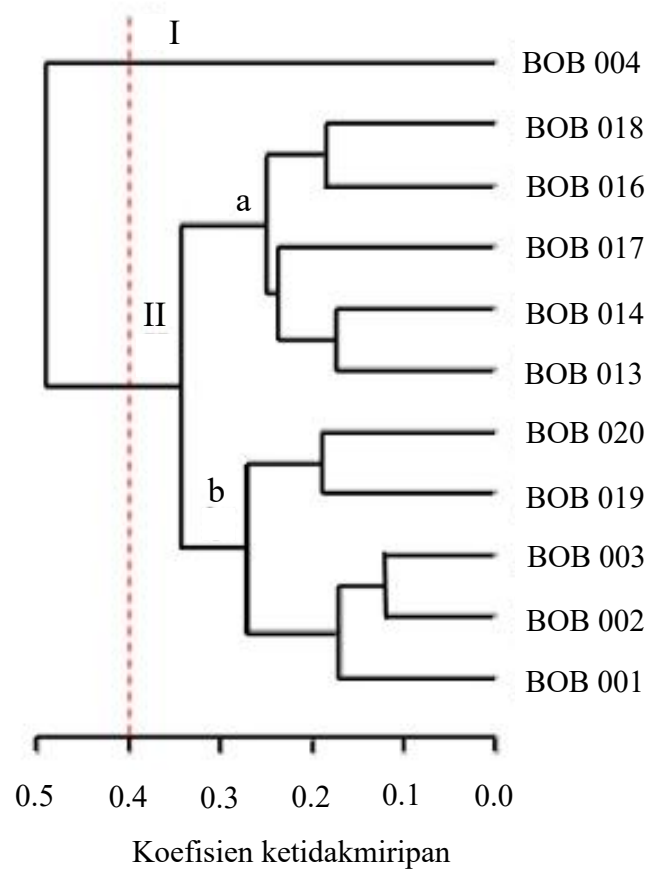

(A) dan umur panen sedang. Kelompok IIb merupakan kelompok genotipe yang memiliki keragaan vegetatifkecil, bobot panen kecil, dan umur panen relatif cepat. Hasil pengelompokan yang didapat sesuai dengan analisis korelasi sebelumnya yaitu ukuran vegetatif yang besar, memiliki umur panen, dan hasil yang lebih besar. Berdasarkan pengelompokan genotipe pada penelitian ini, kisaran ukuran kubis bunga dapat diklasifikasikan menjadi tiga kategori. Tinggi tanaman berukuran tinggi $>65 \mathrm{~cm}$, sedang $65-45 \mathrm{~cm}$, pendek $<45 \mathrm{~cm}$; diameter tanaman berukuran besar $>80 \mathrm{~cm}$, sedang 80-65 $\mathrm{cm}$, kecil $<65 \mathrm{~cm}$; bobot panen berukuran besar $>800 \mathrm{~g}$, sedang 500-800 g, kecil <500 g; dan umur panen yaitu lama $>70$ HST, sedang 70-55 HST, cepat $<55$ HST.

Gambar 1. Dendrogram kubis bunga pada dataran tinggi (A) dan dataran rendah (B)

\section{KESIMPULAN}

Genotipe BOB 021 tidak berbunga di dataran rendah (340 $\mathrm{m} \mathrm{dpl}$ ), dan berbunga di dataran tinggi pada suhu 21.30 ${ }^{\circ} \mathrm{C}$. Karakter vegetatif dan hasil pada dataran rendah lebih tinggi dibandingkan dataran tinggi, umur berbunga dan umur panen di dataran rendah lebih lama dibandingkan dataran tinggi. Karakter hasil yang tinggi dapat dideteksi dari tingginya karakter vegetatif serta lamanya umur berbunga dan umur panen. Pengelompokan genotipe berdasarkan morfologi yang stabil dikedua lokasi, diantaranya kelompok I yaitu BOB 004; kelompok IIa yaitu BOB 013, BOB 014, dan BOB 017; dan kelompok IIb yaitu BOB 001, BOB 002, BOB 003, dan BOB 020.

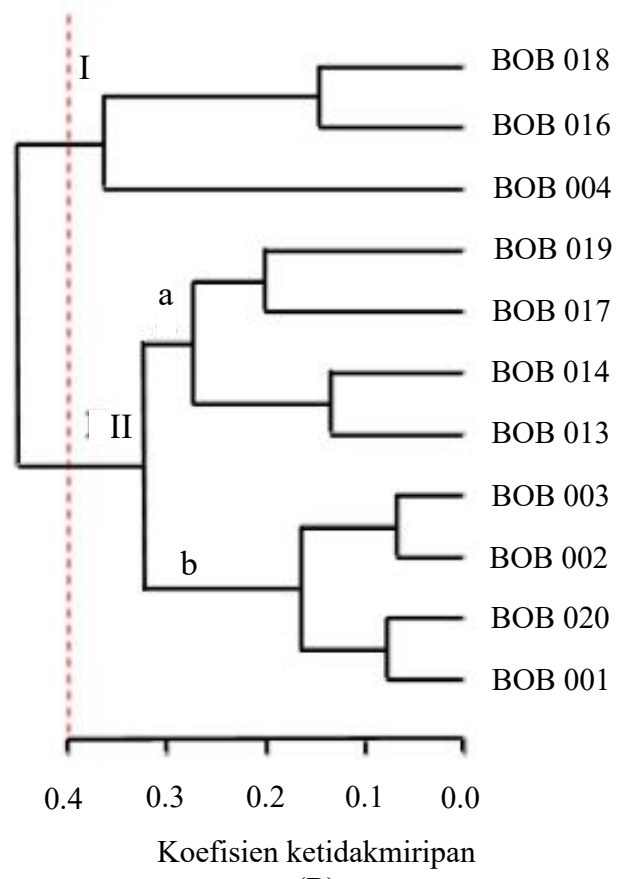

(B) 
[BPS] Badan Pusat Statistik. 2015. Statistik Tanaman Sayuran dan Buah-Buahan Semusim Indonesia. Badan Pusat Statistik, Jakarta, ID.

Cervenski, J., J. Gvizdanovic-Varga, S. Glodgovac. 2012. Variance component and correlations of agronomic traits among cabbage (Brassica oleracea var. capitata L.) maturity groups. Genetika. 44:55-68.

Driedonks, N., I. Rieu, W.H. Vriezen. 2016. Breeding for plant heat tolerance at vegetative and reproductive stages. Plant. Reprod. 29:67-79.

[FAO] Food and Agriculture Organization of the United Nations. 2015. Statistics division crops cauliflowers and broccoli. http://faostat3.fao.org/download/Q/QC/ E. [17 Agustus 2016].

Gomies, L., H. Rehatta, J. Nandissa. 2012. Pengaruh pupuk organic cair R11 terhadap pertumbuhan dan produksi tanaman kubis bunga (Brassica oleracea var. botryris L.). Agrologia 1:13-20.

Hasan, Y., W. Briggs, C. Matschegewski, F. Ordon, H. Stiitzel, H. Zetzsche, S. Groen, R. Uptmoor. 2016. Quantitative trait loci controlling leaf appearance and curd initiation of cauliflower in relation to temperature. Theor. Appl. Genet. 129:1273-1288.

Hossain, M.F., N. Ara, M.R. Uddin, S. Dey, M.R. Islam. 2011. Effect of time of sowing and plant spacing on broccoli production. Trop. Agri. Res. Exten. 14:9092.

[IBPGR] International Board for Plant Genetic Resources. 1990. Descriptors for Brassica and Raphanus. International Board for Plant Genetic Resources, Rome, IT.

Jian, H., B. Yang, A. Zhang, L. Zhang, X. Xu, J. Li, L. Liu. 2017. Screening of candidate leaf morphology genes by integration of QTL mapping and RNA sequencing technologies in oilseed rape (Brassica napus L.). J. Plos One 12:1-16.

[Kementan] Kementrian Pertanian. 2017. Basis Data Statistik Pertanian. http://aplikasi.pertanian.go.id/ bdsp/newlok.asp. [2 Februari 2017].

Kibar, B., O. Karaagac, H. Kar. 2016. Determination of morphological variability among cabbage (Brassica oleracea var. capitata L.) hybrids and their parents. J. Inst. Sci. Tech. 6:31-44.
Marliah,A. Nurhayati, R. Riana. 2013. Pengaruh varietas dan konsentrasi pupuk majemuk terhadap pertumbuhan dan hasil tanaman kubis bunga (Brassica oleracea L.). J. Floratek 8:118-126.

Mondal, S., R.P. Singh, E.R. Mason, J. Huerta-Espino, E. Autrique, A.K. Joshi. 2016. Grain yield, adaptation and progress in breeding for eary-maturing and heattolerant wheat lines in South Asia. Field Crops Res. 192:78-85.

Olesen, J.E., K. Grevsen. 1993. Simulated effects of climate change on summer cauliflower production in Europe. Eur. J. Agron. 2:313-323.

Quiros, C.F., M.W. Farnham. 2011. The Genetic of Brassica oleracea. R. Schmidt., I. Bancroft (Eds.). Genetic and Genomics of the Brassicaceae. Springer Science+Business Media, New York, US.

Safuan, L.O., D. Boer, T. Wijayanto, N. Susanti. 2014. Analisis koefisien lintas berbagai sifat agronomi yang mempengaruhi hasil kultivar jagung pulut (Zea mays Ceritina Kulesh) lokasi Sulawesi Tenggara. Agriplus 24:136-143.

Shah, K., S. Nahakpam. 2012. Heat exposure alters the expression of SOD, POD, APX and CAT isozymes and mitigates low cadmium toxicity in seedlings of sensitive and tolerant rice cultivars. Plant Physiol. Biochem. 57:106-113.

Sundari, T., N. Nugrahaeni, G.W.A. Susanto. 2016. Interaksi genotipe $\mathrm{x}$ lingkungan dan stabilitas hasil biji kedelai toleran naungan. J. Agron. Indonesia 44:16-25.

Tian, T., L. Wu, M. Henke, B. Ali, W. Zhou, G. BuckSorlin. 2017. Modeling allometic relationships in leaves of young rapeseed (Brassica napus L.) grown at different temperature treatments. Front. Plant Sci. 313:1-12.

Trustinah, R. Iswanto. 2013. Pengaruh interaksi genotipe dan lingkungan terhadap hasil kacang hijau. Penelitian Pertanian Tanaman Pangan 32:36-42.

[UPOV] International Union for The Protection of New Varieties of Plants. 2009. Cauliflower: Guidelines for The Conduct of Test for Distinctness, Uniformity and Stability. UPOV, Geneva, $\mathrm{CH}$.

Uptmoor, R., J. Li, T. Schrag, H. Stutzel. 2012. Prediction of flowering time in Brassica oleracea using a quantitative trait loci-based phenology model. Plant Biol. 14:179-189. 
Wahid, A., S. Gelani, M. Ashraf, M.R. Foolad. 2007. Heat tolerance in plants: an overview. Env. Exp. Bot. 61:199-223.

Widiatningrum, T., K.K. Pukan. 2010. Pertumbuhan dan produksi kubis bunga (Brassica oleracea var. botrytis) dengan system pertanian organik di dataran rendah. Biosaintifika 2:115-121.

Wurr, D.C.E., J.R. Fellows. 2000. Temperature influence on the plants development of different maturity types of cauliflower. Acta. Hort. 539:69-74.
Xu, L., K. Hu, Z. Zhang, C. Guan, S. Chan, W. Hua, J. Li, B. Yi, J. Shen, C. Ma, J. Tu, T. Fu. 2015. Genome-wide association study reveals the genetic architecture of flowering time in rapeseed (Brassica napus L.). DNA Res. 23:43-52.

Zhang, L., F. Zheng, W. Qi, T. Wang, L. Ma, Z. Qiu, J. Li. 2016. Irradiation with low-dose gamma ray enhances tolerance to heat stress in Arabidopsis seedlings. Ecotoxic. Env. Savety. 128:181-188. 